\title{
Shift in herders' territorialities from regional to local scale: the political ecology of pastoral herding in western Burkina Faso
}

\author{
Alexis Gonin ${ }^{1 *}$ and Denis Gautier ${ }^{2}$
}

\begin{abstract}
In Burkina Faso, livestock sedentarization programmes are still at the top of policy makers' agendas and at the heart of their discourse, despite huge changes in land cover, land use and territorialities in rural areas. This paper contributes to the literature on the impact of livestock policies targeting the sedentarization of pastoralism in sub-Saharan Africa by specifically highlighting the territorial consequences of such policies. This paper suggests that policies directed at improving livestock governance in a context of climate change and changes in land cover and land tenure need to focus on securing pastoralists' reticular territories, which are made up of corridors and numerous areas of pastureland, rather than on creating disconnected state ranches.
\end{abstract}

Keywords: Territoriality; Pastoral mobility; Livestock policies; FulBe; Burkina Faso

\section{Background}

Pastoral herding in dryland Africa was long misunderstood by scholars, governments and institutions. Pastoralists were generally blamed for their illogical over-accumulation of cattle, their alleged mismanagement of common pastures, which was said to lead to overgrazing and land degradation, and the mobility of their herds, which was perceived as irrational straying by animals. Fortunately, since the mid1990s, as Turner (2011) shows in his recent review, these views have been challenged by a 'new pastoral development paradigm' that 'incorporates a widespread acceptance of the importance of livestock mobility within the context of devolving greater rangeland management authority to local groups'. Pastoral mobility and management of common pastures were revalued, and scholars evidenced the efficiency of pastoralism in the Sudano-Sahelian region of West Africa (Turner et al. 2014). But, regrettably, this scholarly consensus has had difficulty imposing itself in policy and development arenas (Hagmann and Ifejika-Speranza 2010). And finally, abstract conceptualization of mobility, which does not match ground reality, and outdated analysis of pastoralism still underpin livestock policies in Sub-Saharan Africa.

\footnotetext{
* Correspondence: alexis.gonin@univ-paris1.fr

'Université Paris 1 Panthéon-Sorbonne, UMR PRODIG 8586, 191 rue

Saint-Jacques, 75005 Paris, France

Full list of author information is available at the end of the article
}

Laws that deal with pastoral mobility generally fail to protect the resources the pastoralists need (Mattee and Shem 2006; Mwangi 2009).

The primary aim of current livestock policies is clearly to increase the supply of meat and milk to towns, and only secondarily to stop rangeland degradation (Ancey and Monas 2005). Sedentarization of herds, which is assumed to lead to intensification of meat or milk production, is the preferred way to achieve the first goal. Two opposite ways are used to achieve the second goal: to improve the management of common rangelands, policy makers most frequently promote individualization and privatization of commons, or on the contrary, the participation of rural communities in institutionalized committees. The impacts of these policies are well documented: the failure of sedentarization and intensification (Rohde et al. 2006), the ambiguities of participation in common pasture management (Bary 2005; Marty 1993; Mwangi 2009; Oxby 1999) and the adverse effects of the individualization and privatization of rangelands (Archambault 2014; Benjaminsen and Sjaastad 2008; Galaty and Fratkin 1994; Lesorogol 2008). These works show that the two main goals of the advocates of livestock sedentarization, i.e. to increase animal production and to protect the rangeland environment, cannot be achieved sustainably. 
At the same time, the political and geographical marginalization of pastoralists is both a cause and a consequence of ill-founded policies. Wrong-headed institutionalization of community-based resource management (Thébaud and Batterbury 2001) or mismanagement of conflicts between herding and cropping activities (Bassett 1988; Tonah 2003) reinforces the negative effects of marginalization and feeds conflicts between pastoralists on one hand and farmers and state on the other. Unfortunately, the territorial impacts of the mismatch between livestock policies or development practices and actual pastoralists' practices are often glossed over, as pointed out by some authors (Bassett 2009; Marty 1993; Painter et al. 1994; Turner 1999).

To fill the gap concerning territorial impacts, we conducted a field survey in western Burkina Faso, where farmer-herders and FulBe pastoralists have difficulty for the cohabitation of their activities at both local and regional scale. After reviewing policy discourses and official reports since the colonial era and analysing the data from our field study, we notice that livestock and land tenure laws and policies have dramatic territorial consequences, in particular the territorial marginalization of pastoralists, and threaten mobile herding territorialities even when their explicit goal was to reinforce them with the creation of state livestock territories (areas or stock routes).

Here, we define territoriality in a broader sense than Sack $(1983)^{\mathrm{a}}$ as the whole set of socio-spatial relations resulting in modes of resource management, actions, practices, motives, intentions, genesis, personal histories and cognitive recitals that lead to the production of territories. We thus consider that a territory is not necessarily a bounded space under the sovereignty of a political power (Agnew 1994). Rather, following Brunet (1992) and Peluso (2005), we define a territory as a space whose boundaries are demarcated to a greater or lesser extent: (1) that is appropriated by a group through social representations of this space, (2) within which certain practices are permitted based on the explicit or implicit allocation of rights, controls and authority. As a consequence, some territories - including livestock territories - may be the result of an articulation between the sedimentation of daily practices and overarching institutional processes (Gautier et al. 2011; Gautier and Hautdidier 2012). We demonstrate that there is a mismatch between the State's attempt to secure pastoralism by creating state livestock territories and mobile herders' territorialities. As a result, sedentary farmer-herders' territorialities are being strengthened by livestock and land policies in western Burkina Faso.

\section{Study area and methodology}

Burkina Faso is a land-locked country that overlaps Sahelian and Sudanian zones. Annual rainfall ranges from $400 \mathrm{~mm}$ in the north to $1,100 \mathrm{~mm}$ in the south.
Variations in rainfall in space and over time are of the greatest importance for pastoralists who follow water and pasture resources along north-south transhumance routes (Figure 1).

Our study was conducted in the western part of Burkina Faso. This region is regarded as the country's agricultural breadbasket and is generally contrasted with the northern and eastern regions and the Sahel, which are regarded as the great herding regions. However, livestock raising is also a very important yet underestimated economic activity in western Burkina Faso. There are 3.3 million head of cattle in the region ${ }^{\mathrm{b}}$, which accounts for one third of the total cattle population in the country. Although there have been major migrations of farmers from the Mossi plateau since the 1970s, the population densities of rural areas are lower in western Burkina Faso than in the rest of the country; densities range from 20 to 40 people per square kilometre versus 60 to 80 people per square kilometre on the Mossi plateau, which is considered to be overexploited. Since Independence, regional development has been based on agriculture, particularly on cotton (Schwartz 1997; Bassett 2001). But cattle breeding by both farmers and pastoralists has become a key issue in the region (Petit 2000; Botoni Liehoun et al. 2006; Augusseau 2007).

In 2012 and 2013, we conducted field research in the western region of Burkina Faso to collect data on the territorial impact of land tenure policies, livestock husbandry policies and rural development policies on livestock rearing. First, we gathered data on the definition and implementation of the policies. We reviewed Burkinabé laws, policy reports and national and colonial archives. We interviewed top civil servants at the Ministry of Livestock (Ministère des Ressources Animales, MRA) along with 40 experts (NGO staff, livestock administration agents, private consultants, local political representatives).

Second, we collected specific data on the consequences of land tenure policies, livestock husbandry policies and rural development policies on herders' action spaces and on cattle mobility. To review changes in the extent of pasturelands (Figure 2), we processed Landsat images acquired in $2010^{\mathrm{C}}$ using a supervised classification based on samples of cropped areas, orchards, pastures in the plains, pastures in the hills and woodlands. The sample areas were delimited on aerial photographs, and some were checked by GPS during the field survey. We conducted a diachronic analysis of the land cover in the Samorogouan livestock ranches. Sample areas were delimited on aerial photographs from 1986 and 2010, while an additional supervised classification was performed on a Landsat image acquired in 1986. Next, we organized 38 workshops with livestock owners in the villages and in the surrounding hamlets and FulBe compounds in four municipalities sampled from north to south according to rainfall and agricultural 


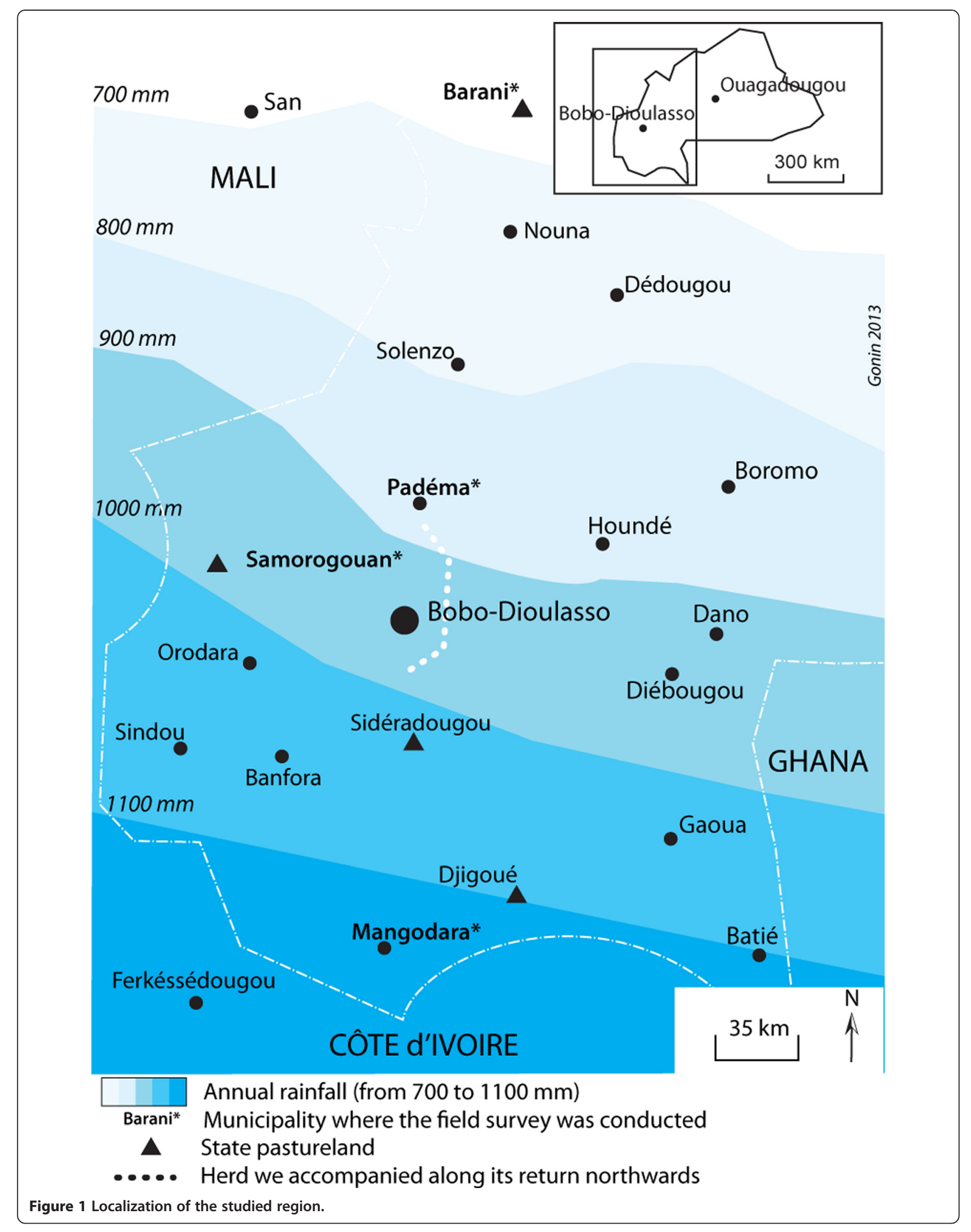




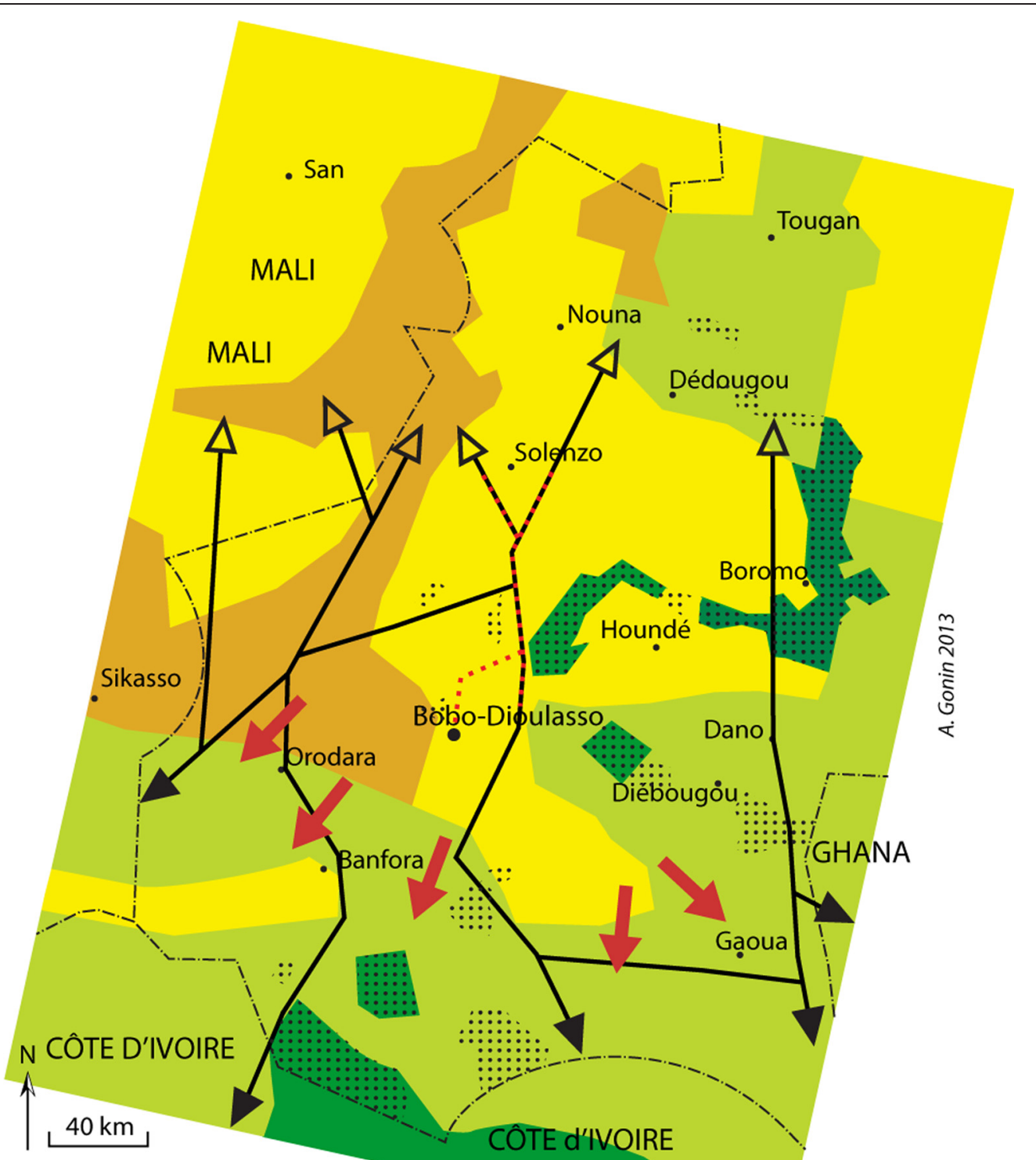

\section{Complementary pasturelands}

Cropped area with very little pastureland

Cropland and orchards with pastureland in the plain

Pastureland in the hills in the rainy season with a few cropped areas

\section{North-south herding movements}

Stock route

Direction taken by the herd in the rainy season

Direction taken by the herd in the dry season

.... Cattle corridor delimited in 2013-14

\section{The reduction in pasturelands}

Spread of croplands

: $:$ Game reserves

Sources : Landsat 5 october-november 2010; USGS; field survey

Figure 2 FulBe's reticular territories. 
land use (Figure 1). Barani, Padéma and Mangodara are located along the same transhumance stock route; Samorogouan was chosen because a state pastoral territory was implemented in this municipality in 1975. In all, we visited 15 villages, 18 hamlets and 13 FulBe compounds. The objectives of the workshops were to trace the history of the settlements and identify tenure issues, to inventory the herds belonging to the settlement and to characterize the mobility of the herds in space and over time on maps drawn by the local people. Then, based on the results of the workshop, 207 actors were chosen for interview according to their socioeconomic status and the mobility framework of their herd: 123 pastoralists (including 96 owners and 27 herders) and 84 farmer-herders. The aim of the interviews was to gather data on cattle mobility and on the territorial rationales behind the herders' choices to move from one point to another. In addition to the workshops and interviews in the villages covered by the survey, 70 pastoralists were interviewed along one of the three $600-\mathrm{km}$ transhumance routes of western Burkina Faso (Figure 2), including 10 in-depth interviews with families of pastoralists (interviews with the father, sons, uncles and brothers located across the region). Finally, we accompanied the herd belonging to one of the families for a 84- km stretch on its way home to the north in June 2012 to cross-check the information and to better understand the impact of territorialities on their herd's mobility.

The information gathered from reports and interviews with experts was crossed checked with the results of our analysis of satellite images, with the information we collected during workshops and interviews with producers and field observations to ensure accurate assessment of herders' territorialities and the impact that policies have had on them.

\section{Co-existence of two livestock systems and associated territorialities}

Recent trends in livestock systems in Burkina Faso

The International Union for Conservation of Nature (IUCN) (2006) considers that livestock pastoralism is a significant economic contributor, as it contributes to $24 \%$ of the agricultural gross domestic product (GDP) of Burkina Faso. Historically, FulBe people were by far the biggest cattle owners in Burkina Faso. FulBe people still herd $70 \%$ of the total cattle population (Wayne 2006), although they own only $55 \%$ of national livestock and represent only $11 \%$ of herders ${ }^{\mathrm{d}}$. As such, in social representations, FulBe are seen as pastoralists even when they have been settled for decades on land they currently use to grow crops, and they are still contrasted with other ethnic groups who are considered to be farmers even though they own more livestock than the territory belonging to their village can feed all year long, and whose 'action space' (Painter et al. 1994) is bigger than their 'terroir' (Sautter and Pélissier 1964). Nevertheless, since the beginning of $1990 \mathrm{~s}$, farmers who invest the money they make on cash crops in cattle (Vall et al. 2006) now own $45 \%$ of national livestock and represent $89 \%$ of livestock owners (Plan d'actions et programme d'investissements du sous-secteur de l'élevage 2010-2015 2010). Even though farmers usually entrust the care of their herd to sedentary FulBe (Bassett 1994), the social and political permanency that opposes farmer and herder communities is strange since both combine farming and herding activities. Despite the convergence of the two rural systems, FulBe people are nevertheless considered by others (and by themselves) culturally and economically as herders, even if the majority are now sedentary and share closed territoriality with farmers. Due to this social and cultural permanency, and due to very different practices typical of pastoral mobility (Turner et al. 2014), the legacy of two co-existing territorial systems is still very meaningful.

\section{Two overlapping livestock territories}

The extent of pastoral territories established by FulBe is usually regional rather than local. A pastoralist's territory consists of (1) the 'home territory' (terroir d'attache (Marty 1993)), where the family patriarch has lived for 30 or 40 years; (2) the transhumance route, knowledge of which fathers passed on to their sons and that have remained the same for more than 40 years; and (3) the transhumance territories explored each year in the quest for grass. Two components of FulBe's livestock territory can be located from 30 to $600 \mathrm{~km}$ apart. Transhumant herds usually contain about 100 individuals. Their movements are sufficiently regular from year to year (Gautier et al. 2005; Brottem et al. 2014) to generate stable herders' territorialities. Mobile herders' territories are networks made up of nodes (with the home territory and transhumance territories) with links between these nodes (the transhumance route): they can be conceptualized as reticular territories. They have fuzzy limits, and enforcement by pastoralists is limited (Benoit 1979). At a regional scale, pastoralists have a profound knowledge of the network of pastures and of the route followed by the livestock. At local scale, they draw a fine distinction between hills (ferlo and fukkawo in Fufulde), plains (seeno, gesa, seyno and guyfan) and bottomland (cofol) pastures (Vall and Diallo 2009; Dongmo et al. 2012).

In comparison, the farmer-herders' territories are limited to a small region. They are appropriated through farming practices and land tenure rights, based on the native or migrant narratives (Lentz 2005) that frame their territoriality. Even if the action space of their herds may extend into territory belonging to neighbouring villages, the control exerted by farmer-herders over their livestock territory is more meaningful than that by 
pastoralists, due to their relationships with central and local authorities. Farmer-herders are well represented on local councils and play an active role in territorial planning and in the control of resources.

\section{Herding in regional pastoral territories is environmentally more efficient than sedentary livestock breeding in local territories}

An increasing proportion of all the cattle in the country is herded locally in farmer-herders' territories even though it has been demonstrated since the pioneer works of Horowitz (1979) and Sandford (1983) that mobile herding at regional scale is environmentally more efficient. Scoones (1999) refutes the idea that ecosystems are closed and self-regulated and that environmental changes are embedded in direct relationships between human activity and the environment. On the contrary, according to evidence from the 'new ecology', ecosystems are in disequilibrium (Zimmerer 1994; Turner 1998; Zimmerer 2000). In this context, building a reticular territory that enables herd mobility at regional scale is a good adaptive strategy in the face of uncertainty (Scoones 1994).

From an economic point of view, in a Sahelo-Sudanian environment, pastoralism is much more profitable than sedentary livestock breeding that is limited to local territories. The first papers to provide evidence were published in the 1980s (Livingstone 1991; Upton 1986; de Ridder and Wagenaar 1986; Western 1982; Colin de Verdière 1995). For example, in Bostwana and in the Sahelian zone of Mali, Breman and De Wit (1983) demonstrated that, with transhumance herding, animals produced from two to ten times more protein per hectare than animals in sedentary herds.

Despite this evidence for the efficiency of pastoralism over sedentary livestock breeding and despite a certain willingness of policy makers to preserve pastoralists' territorialities with the settlement of stock routes, livestock is increasingly being herded in local territories. FulBe's and farmers-herders' territorialities thus co-exist at the local scale.

\section{The fragmentation of mobile herders' territorialities in Burkina Faso}

Land tenure and rural development policies have jeopardized mobile herders' territorialities since Independence. Three arguments that emerged from our qualitative field survey confirm this: the absence of legislation on rangelands, the failure to apply the general law on pastoralism voted in 2002 and the precedence given to agriculture by policy makers in western Burkina Faso.

\section{Absence of legislation on rangelands}

Until 2002, no law dealing with pastoral resources had been legislated. In the major land tenure and rural land planning reforms in 1986, 1992 and 1996 (Réformes Agraires et Foncières, RAF), there was no specific mention of rangelands or pastoral areas. Uncropped and unappropriated spaces were de facto regarded as belonging to the state since the colonial era and despite ongoing decentralization. However, the state had taken very few measures to secure these spaces or to guarantee pastoralists' activities and mobility. A new major land law was passed in 2009 (Law 034-2009 portant régime foncier rural) promoting local charters to regulate ownership, tenure and access to land. Pastoral land use is explicitly mentioned in the sixth article of the law. The participation of all the members of a local community is required to draw up a local charter. The application of the law is being tested in a few municipalities ${ }^{\mathrm{e}}$. The first experiment was conducted in the municipality of Padéma between 2004 and 2009 to define the facilities that the law would provide in 2009. We analysed this experiment, which largely inspired the drafters of the law 2009-034. We discovered that the pastoralists did not take part in drawing up the Padema charter (this result agrees with that of Bary (2005), Marty (1993) and Painter (1994)) and the formalization of transactions (donation, sale or rental of plots of land) concerned only croplands, not village grazing lands. Moreover, the law is to be applied at the municipal scale, and no provision has been made to protect regional stock routes and transhumance territories.

\section{Failure to apply the pastoral law of 2002}

The Framework law on pastoralism (Loi d'orientation relative au pastoralisme LORP 2009-034) was adopted in 2002. This is the first framework law on pastoralism ever voted in Burkina Faso. The implementing decrees of this act were adopted five years after the law was passed. Several types of pastoral areas (village grazing land, forests, fallow fields, fields after harvest, stock routes, etc.) and rights of access to water and crop residues are guaranteed by the state and by the local community who are held responsible for the protection of these resources. Herd mobility is also recognized by the law. However, it is channelled in stock routes and hindered by a compulsory transhumance certificate. In practice, the law is not applied. The state fails to protect rangelands and regional stock routes from the extension of cropland by surrounding farmers or migrants, which jeopardizes the mobile herders' territorialities as confirmed by two pieces of evidence we collected during our field survey.

The first evidence came from the case study in Samorogouan. In 1975, a state pastoral area was created in the department of Samorogouan. It was funded by the World Bank until 1984 and Sankara's coup d'état. However, the limits of the pastoral area were not clearly established by the state until 2012, and between 1975 and 2012, the state lost control over the pastoral area, 
which was originally defined for sedentary cattle but is in practice also a transhumance territory. In August 2009, a FulBe herd damaged the crop in a farmer's field located within the boundaries of the pastoral area. This was a strategy applied by the FulBe to call on the state to ensure the pastoral area is respected by farmers. A trial was held in the district capital, Orodara, in which the FulBe were convicted, even though the verdict has never been officially published (Hochet and Guissou 2010). This court decision appears to be in contradiction with the 50th article of the law 2002-034. The decision supported the farmers and the extension of cropland into the pastoral area that should have been protected by the state. According to our own remote sensing analysis of Landsat 5 images, rainy season pasturelands accounted for $92 \%$ of the 125,000 ha of the pastoral area in Samorogouan in 1986 versus only 61\%, two and half decades later in 2010 due to the extension of croplands. Samorogouan is evidence for the state's failure to apply the law 2002-034 and to defend mobile herders' territorialities.

The second evidence came from our field survey on livestock routes that the state should have been protecting against land encroachment. One of the only concrete measures taken by the Burkinabé government in favour of pastoralism in the last 50 years has been to define stock routes, although with the aim of controlling mobility rather than encouraging it, plus controlling (and taxing) the FulBe themselves. But the stock routes delimited in the 1970s have since been encroached by fields, with no administrative action taken against the encroaching farmers. According to our interviews with experts, the local authorities never ask if the damaged field is located in a pasture or on a stock route. Furthermore, no new transhumance route was delimited in western Burkina Faso until 2012. At the start of the rainy season, when pastoralists return to their homes in the north, their herds often come across fields obstructing the historic and/ or officially delimited stock route. When we accompanied a returning herd on its way north for a 84-km stretch in June 2012, we were forced to circumvent cropped fields 17 times; the herd went through cropped fields five times, thereby triggering conflicts with the farmers who were working in them. To avoid these conflicts, many pastoralists now prefer to return north earlier, even if the grass there has not yet grown.

In 2012, two projects for the delimitation of stock routes in the western region were led by two NGOs, SNV (the Netherland aid agency) and GRAF (Groupe d'Action sur le Foncier, Action Group on Land Tenure, an international NGO), in partnership with newly created municipalities. Like the experiments described by Moritz et al. (2013) in northern Cameroon and by Moutari and Giraut (2013) in southern Niger, their aim is to facilitate mobile herding. But surprising as it may seem, in western Burkina Faso, only one representative of the pastoralists attended the meetings organized by GRAF to map the stock routes, whereas all the mayors of the municipalities, proponents of the interests of settled populations, attended (Gonin and Tallet 2012b). Apart from which, due to lack of funding, the two projects have only delimited part of the regional transhumance route (Figure 2).

\section{Priority given to agriculture to the detriment of mobile herders' territoriality}

The general rural policy orientation has always promoted agricultural development in western Burkina to the detriment of mobile herders' territoriality. Since the 1970s, the continuous extension of croplands, which has led to the fragmentation of mobile herders' regional reticular territories, is partly due to the priority given to agriculture by policy makers (Tallet 1997). For instance, the state promoted the development of cotton in the western region through a company named Sofitex (Société burkinabè des fibres textiles), in which the state is one of the main stakeholders (Gray and Dowd-Uribe 2013). The incentives offered to crop cotton triggered a general extension of croplands, first to the north of BoboDioulasso, in the home territories, and then southward, in the transhumance territories (Figure 2) (Gonin and Tallet 2012a). Sofitex also introduced animal-drawn ploughing, which enabled the rapid expansion of fields (Tersiguel 1995) to the detriment of rangelands. Analysis of satellite images showed that rainy season rangelands decreased from $58 \%\left(54,400 \mathrm{~km}^{2}\right)$ of the total area of western Burkina Faso in 1992 to $48 \%\left(45,200 \mathrm{~km}^{2}\right)$ in $2002^{\mathrm{g}}$, whereas according to rough estimations provided by the Ministry, livestock was increasing by $2 \%$ each year.

Transhumant herds move southward during the dry season to meet the first rains and the first flush of grass. At the beginning of the rainy season, they turn northwards toward their 'home territory' and their rainy season pastures (Figure 2). But encroachment of stock routes by crop fields hinders herd mobility between pasturelands in the north and south. Interviews and observations in villages to the north of Bobo-Dioulasso showed that during the agricultural season, herds are confined to barren hills which are the only remaining pasturelands at this period: in the vast majority of villages, other rangelands had been encroached by crop fields. In addition, since the 1990s, cashew nut and mango orchards have spread throughout the southern rangelands, (in 1980, orchards accounted for 1,000 versus 80,000 ha today ${ }^{\mathrm{h}}$ in the six districts that make up the south-western region). This extension is an increasing problem for pastoralists. For instance, in the 1990s, transhumant FulBe used to come to Mangodara, where 
there has been a dramatic increase in cashew orchards (Audouin and Gazull 2014). The herds arrived in February at the beginning of the cashew nut harvest (the nuts are also eaten by cattle). It is very difficult for herders to avoid the orchards, which are scattered throughout the bush. At the end of 1990s, violent conflicts broke out and today pastoralists no longer come to Mangodara. Government representatives attempted to mediate between FulBe pastoralists and local farmers, but they failed to grasp the opportunity to prevent conflicts by preserving pasturelands alongside orchards. Consequently, at the beginning of the 2000s, transhumant herders changed from Mangodara to Djigouéra (Figure 1), where there were fewer cashew orchards. In vain, in Djigouéra, cashew orchards are now also expanding, and mobile herders will have to find another territory for their transhumance.

In sum, the failure by state authorities to protect the northern and southern rangelands jeopardizes the regional reticular territory of mobile herders.

\section{A political bias toward sedentary livestock territories}

Overall, the orientation and enforcement of livestock policies are still biased in favour of sedentary cattle breeding, hence reinforcing sedentary herders' territories. In Senegal (Ancey and Monas 2005) and Nigeria (Milligan and Binns 2007), policy makers still argue for the permanent settlement of herders and for the intensification of livestock production. In Burkina Faso, the same guiding motif appears in every report on general livestock policy orientations: 'transforming traditional herd-breeding into intensive or semi-intensive livestock husbandry' (Plan d'actions et programme d'investissements du sous-secteur de l'élevage 2010-2015 2010; Politique nationale de développement durable de l'élevage au Burkina Faso 2010; Stratégie d'aménagement, de sécurisation et de valorisation des espaces et aménagements pastoraux 2009). Based on this principle, a new livestock policy is being designed. It is likely to fail, but the very attempt to apply sedentarization measures will reinforce farmer-herders and their territories, with no consideration given to pastoralists and their successful adaptive strategies to climate changes (Turner and Williams 2002; Turner 2009; Mertz et al. 2010).

\section{Restoration of an old policy}

A constant feature of livestock policies in the Sahel is that states aim to keep mobility under strict territorial control. As a result, Burkinabé policy makers propose the creation of new delimited pastoral territories under the control of local authorities. The main goal is to increase the number of pastoral territories from 24 in 2013 to 120 in 2025 in the framework of decentralization. These communal pastoral areas should cover between 1,000 and
130,000 ha. They are envisaged as 'development centres' whose purpose is to propagate modern livestock rearing as an 'innovation'. The goal is to intensify production on fattening farms through the use of fodder and the genetic improvement of cattle breeds. According to policy makers, the so-called 'traditional herders' will appreciate the efficiency of modernized methods of improving production and will imitate these models. This policy recalls the World Bank's ranch projects in the 1970s (see below), which were a failure.

The sedentarization policy of the World Bank and the ranches of Samorogouan Projects concerning cattle breeding account for only 7\% of World Bank rural production projects in sub-Saharan Africa and 3.3\% of funds (all projects with at least one breeding component amount to $14 \%$ of rural production projects and $7.6 \%$ of funds). A total of $27 \%$ of all the funds spent on livestock between 1968 and 2010 were paid out between 1968 and 1980 to set up ranches based on the American model. The World Bank promoted ranches first in East Africa and then in West Africa and southern Africa as a way of intensifying herding. The ranches of Samorogouan, set up in 1975 in the framework of the 'Livestock Project of Western Volta' (the former name of Burkina Faso), were in line with this policy. Originally called the 'Development Center of Collective Ranches' (CARC), they aimed to guide pastoralists toward intensification. An agreement was drawn up between the state and customary chiefs according to which the chiefs gave up their land tenure rights and yielded their land management prerogatives to national authorities. The creation of nine ranches each containing 1,000 animals was predicted, based on the model of Samorogouan. The animals were to remain the property of individual pastoralists, but herding was to be managed collectively. Infrastructures were created to enable the cultivation of fodder, and feedlots were built. Tsetse flies were eradicated. The programme was progressively abandoned in the 1980s and ended in failure, like all the other ranches managed by the World Bank across Africa in the same period (Keya 1991; Boutrais 1990). Only four ranches flourished at Samorogouan; many pastoralists fled the area because of the recrudescence of tsetse flies and many cattle died from trypanosomiasis. In 1984, the communist Thomas Sankara led a coup d'état. In the context of the Cold War, the World Bank stopped funding Burkina Faso, which had direct adverse effects on the Samorogouan project. Sankara renamed the programme the 'Executive Center of the Intensification Zone of Traditional Herding' ('CEZIET' in French). Once again, the terms used in this name originated in the colonial legacy that Sankara was fighting. But without funds, the Samorogouan ranch could no longer be controlled and managed. Technicians and 
civil servants left, and with no new investments, the area appeared to be abandoned by the state. Since that time, native farmers have extended their fields and settled migrants in the pastoral area. From the mid-1980s, the population of farmers rapidly increased (Nelen et al. 2004). The state waited until 2012 to come up with a restoration project.

\section{A policy doomed to failure?}

Several geographic and social arguments that emerged from our field research and from historical reports suggest that the creation of livestock territories as planned by Burkinabè policy makers may be wishful thinking.

- The great majority of the 24 existing pastoral areas are already encroached by croplands like in Samorogouan, even if this is understated by state agents. If the government wants to establish new pastoral areas, it needs to enforce its policy immediately.

- To create new pastoral areas entails negotiating tenure land rights with native landowners. Local power relations need to be shifted in favour of pastoralists. Once again, the case of Samorogouan (Nelen et al. 2004; Hochet and Jacob 2012) demonstrates that ambiguities concerning the status of pastureland need to be clarified from the start; otherwise, the expansion of cropland will jeopardize the viability of the pasture area.

- Barani is the only pastoral area covering 50,000 ha that is protected from cropland encroachment. This is mainly due to the fact that it is an old FulBe kingdom where pastoralists have retained power over land and resources. The pastoral area was established in the 1990s, in a bottom-up approach. These two crucial features - which are found nowhere else - explain why Barani is a sustainable pastoral territory. It is worth noting that this pastoral area has never been used for intensification trials. On the contrary, these rangelands are incorporated in the local pastoralists' grazing system.

- Institutionalized pastoral zones are highly unlikely to become models of intensification for the so-called 'traditional' pastoralists. The diffusion of an intensified stockbreeding model to the whole rural world is difficult to imagine, since intensified breeding farms are mainly located on the outskirts of towns (Moritz 2012) and are usually owned by current or former politicians or civil servant investors called agro-businessmen. The high investment costs are out of reach of the great majority of pastoralists (Hamadou and Bouyer 2007).

The creation of local livestock territories is thus likely to fail. Although the policy has not yet been implemented, and will be very difficult to implement, attempts to apply it already have consequences for herders' territorialities.

\section{A policy that favours farmer-herders and enforces their livestock territorialities}

If it is applied, the policy to create local livestock territories will favour farmer-herders' territories rather than agro-pastoralists' territories. Firstly, it was conceived at the inter-village scale, which corresponds to the action space of sedentary farmer-herders. As far as mobile pastoralists are concerned, few transhumance stock routes have been delimited and a regional scheme for the preservation of a rangeland reticular territory in western Burkina Faso has not been created to connect the local pastoral territories, thereby highlighting political orientations regarding livestock. Secondly, in Samorogouan and Mangodara, farmer-herders are better represented than pastoralists on local councils (municipal councils and village development councils, $C V D$, whose members are people who are influential in the village and which are the reference for the village land planning project). In the Samorogouan state ranch, sedentary farmer-herders head the herders' most powerful local associations. The members of the management committees of the pastoral territory, which were established in 2011, are mainly sedentary farmer-herders. As a result, they are likely to have the power to control the herding resources of existing or planned state livestock rearing territories to their own advantage. Two pieces of evidence from our field survey support this hypothesis. Firstly, in the best possible case, if cropping pressure is not too high, state livestock rearing territories may preserve the last bush areas in the territory of villages during the rainy season mainly for the benefit of local farmer-herders. At local scale, there is not enough pasture for all the cattle. The biggest herds have to leave their home territory. The 40 people (30 FulBe people and 10 farmer-herders) we interviewed each own more than 80 cattle. During the rainy season, $60 \%$ of these FulBe people have to leave the local territory, compared to only $40 \%$ of farmer-herders. FulBe people are thus the first to be affected by a reduction in available pastureland. Secondly, like in Samorogouan, the great majority of the 24 existing pastoral areas are already encroached by croplands, even if this is minimized by state agents. The remaining uncultivated lands in the majority of village territories are progressively shrinking due to the extension of cropping on arable lands. The only pasturelands that are available during the cropping season are often barren hills. The extension of cropland is due to the settlement of migrant farmers by native farmer-herders who have customary rights to the land in the pastoral area. Thus, if the management of new pastoral areas is delegated to local committees, the sedentary farmer-herders, who are the 
most powerful local actors, will logically manage these areas to their own advantage. They are extremely likely to support the extension of croplands and appropriate the remaining pasturelands for their herds, as already happened in Samorogouan.

This body of evidence strongly suggests that the territorial consequences of livestock policies in Burkina Faso will be negative for pastoralists. On the one hand, it reifies local territories for sedentary breeding. On the other hand, it contributes to the fragmentation of mobile herding territories, despite the fact that this kind of livestock husbandry has proven its environmental efficiency.

\section{Discussion and conclusion}

In this paper, we have identified the main links in the chain of causality that has led to FulBe territorialities being challenged at regional and local scales. We have argued that, despite scientific and economic evidence for the efficiency of pastoralism, all the rural development policies since the colonial era and even during the Sankara anti-colonialist period have always favoured sedentary herding, with livestock confined to small strictly controlled areas. We have demonstrated that these policies have three territorial consequences: (1) the livestock territories that were created by the state to facilitate herd mobility are now usually controlled by farmer-herders; (2) at local scale, the territorialities of permanently settled farmers who capitalize on livestock are reinforced despite the fact that their herding action space extends beyond the boundary of their village territory; and (3) at the regional scale, these policies weaken pastoralists' reticular territorialities, which are based on socio-spatial relations built up with farmers to acquire and secure access to water, pastures and stock routes between the anchored pastoral territories.

The state now wishes to develop new pastureland territories under its own control or under the control of the municipalities; but their intentions do not match current herding practices. The fragmentation of reticular FulBe territorialities at regional scale is to a large extent due to the extensive cropping practices, but it is reinforced by these top-down territories devised at local scale. The articulation between dry season pasturelands in the south and rainy season pasturelands in the north has been destroyed by 50 years of rural policies that deny the efficiency of pastoralism. But, even though pasturelands are shrinking rapidly at regional scale, there is still time to change the orientation of these policies. Based on our conclusions, if the state intends to secure some territories as areas of transformative adaptation to climate change, the areas should comprise reticular territories made up of stock routes and numerous pasture areas rather than disconnected state ranches.
To date, local administrations have been less than strict with sedentary farmer-herders who take advantage of the situation to strengthen their own territorialities. Farmer-herders are powerful in local councils and may appropriate and orient the development of these newly created or planned state livestock breeding territories to their own advantage, whereas the FulBe are not politically organized and there are very few FulBe representatives at village or municipality levels. Farmers who became farmer-herders could control local pasturelands and limit access to them (including to crop residues) except by their own herds, i.e. at the expense of mobile pastoralists' herds that will consequently only be able graze the non-arable margins of village territories. Yet ironically, the most noteworthy result of livestock policies today is that all the livestock systems are jeopardized, including 'sedentary' livestock, as there are now too many cattle to feed all year long on village territories, as a result of which, these cattle are partly incorporated in pastoralists' herds. The entire livestock sector is weakened, whereas since Independence, it has been the third then fourth source of export revenues. Sedentary cattle breeding is still far from achieving the productivity of pastoralism and cannot replace pastoralism as a provider of cheap stock for the sector.

Moreover, beyond virtuous discourses, the Burkinabé state does not commit itself to re-establishing the balance of power on land access in favour of pastoralists. This state of affairs is easy to maintain since pastoralists do not commit themselves to power institutions and perceive themselves as marginal. FulBe pastoralists, who have little political clout and who are not sufficiently organized to be adequately represented in local and national policy forums, are the losers of policies based on the old controversial discourse that was above all aimed at controlling them in space, and by immobilizing them in space, immobilizing them in time.

\section{Endnotes}

${ }^{a}$ According to Sack, territoriality is 'the attempt by an individual or group to influence, affect or control objects, people and relationships by delimiting and asserting control over a geographic area'.

${ }^{\mathrm{b}}$ Ministère des Ressources Animales, statistical report 2009.

${ }^{\mathrm{c}}$ Images were downloaded from http://earthexplorer. usgs.gov/

${ }^{\mathrm{d}}$ Ministère des Ressources Animales, statistical report 2009.

${ }^{\mathrm{e}}$ Project funded by the Millenium Challenge Account.

${ }^{\mathrm{f}}$ According to this article, anyone who clears a field in a pastoral area belonging to the state shall be punished by a fine from 100,000 to $300,000 \mathrm{XOF}$ and/or be sentenced to prison for one to three months. 
${ }^{\mathrm{g}}$ Base de Données sur l'Occupation des Terres. IGB, IGN, 2002.

${ }^{\mathrm{h}}$ Enquêtes permanentes agricoles, Ministry of Agriculture, 2011.

\section{Competing interests}

The authors declare that they have no competing interests.

\section{Authors' contributions}

AG carried out all the field studies and data process. The analysis of the data in a political ecology perspective as well as the paper writing have been realized by both $A G$ and $D G$.

\section{Author details}

'Université Paris 1 Panthéon-Sorbonne, UMR PRODIG 8586, 191 rue Saint-Jacques, 75005 Paris, France. ${ }^{2}$ CIRAD UR BSEF, seconded scientist to CIFOR, 06 B.P. 9478, Ouagadougou 06, Burkina Faso.

\section{Received: 24 July 2014 Accepted: 22 January 2015}

Published online: 06 April 2015

\section{References}

Agnew, John. 1994. The territorial trap: The geographical assumptions of international relations theory. Review of International Political Economy 1: 53-80.

Ancey, Véronique, and Georges Monas. 2005. Le pastoralisme au Sénégal, entre politique « moderne » et gestion des risques par les pasteurs. Tiers-Monde 46: 761-783. doi: 10.3406/tiers.2005.5610.

Archambault, Caroline. 2014. Young perspectives on pastoral rangeland privatization: Intimate exclusions at the intersection of youth identities. European Journal of Development Research 26: 204-218. doi:10.1057/ ejdr.2013.59.

Audouin, Sarah, and Laurent Gazull. 2014. Les dynamiques d'un système d'innovation à travers le prisme des diffusions spatiales. Le cas de l'anacarde au Sud-Ouest du Burkina Faso. L'Espace Géographique 43: 35-50.

Augusseau, Xavier. 2007. Évolution des systèmes agro-pastoraux dans le sud-est du Burkina Faso, interactions et dynamiques territoriales. Montpellier 3 Paul Valéry: Thèse de doctorat, Montpellier.

Bary, H. 2005. Dealing with mobility in decentralisation: Risks and opportunities for pastoralists. Bulletin Royal Tropical Institute 356: 49-60.

Bassett, Thomas J. 1988. The political ecology of peasant-herder conflicts in the Northern Ivory Coast. Annals of the Association of American Geographers 78: 453-472.

Bassett, Thomas J. 1994. Hired herders and herd management in Fulani pastoralism (Northern Côte d'Ivoire). Cahiers d'Etudes africaines 34: 147-173.

Bassett, Thomas J. 2001. The peasant cotton revolution in West Africa. Cambridge: Cambridge University Press.

Bassett, Thomas J. 2009. Mobile pastoralism on the brink of land privatization in Northern Côte d'Ivoire. Geoforum 40: 756-766. doi: 10.1016/j.geoforum.2009.04.005.

Benjaminsen, Tor A, and Espen Sjaastad. 2008. Where to draw the line: Mapping of land rights in a South African commons. Political Geography 27: 263-279. doi: 10.1016/j.polgeo.2007.10.006.

Benoit, Michel. 1979. Le chemin des Peul du Boobola: contribution à l'écologie du pastoralisme en Afrique des savanes. Paris: Orstom éditions.

Botoni Liehoun, E, P Daget, and J César. 2006. Pasture activities, biodiversity and pasture vegetation in the western area of Burkina Faso. Revue d'Élevage et de Médecine Vétérinaire des Pays Tropicaux 59: 31-38.

Boutrais, Jean. 1990. Derrière les clôtures... Essai d'histoire comparée de ranchs africains. Cahiers des Sciences Humaines 26: 73-95.

Breman, Henk, and CT De Wit. 1983. Rangeland productivity and exploitation in the Sahel. Science 221: 1341-1347.

Brottem, Leif, Matthew D Turner, Bilal Butt, and Aditya Singh. 2014. Biophysical variability and pastoral rights to resources: West African transhumance revisited. Human Ecology 42: 351-365. doi: 10.1007/s10745-014-9640-1.

Brunet, Roger, Robert Ferras, and Hervé Théry. 1992. Les mots de la géographie: dictionnaire critique. Paris: Reclus - La documentation française.

Colin de Verdière, Philippe. 1995. Étude comparée de trois systèmes agropastoraux dans la région de Filingué (Niger); les conséquences de la sédentarisation de l'élevage pastoral au Sahel. Thèse de doctorat. Paris: INA Paris-Grignon.
De Ridder, N, and KT Wagenaar. 1986. Energy and protein balances in traditional livestock systems and ranching in eastern Botswana. Agricultural Systems 20: 1-16. doi:10.1016/0308-521X(86)90032-6.

Dongmo, Aime-Landry, Eric Vall, Mohamadoun Amadou Diallo, Patrick Dugue, Aboubakar Njoya, and Jean Lossouarn. 2012. Herding territories in Northern Cameroon and Western Burkina Faso: Spatial arrangements and herd management. Pastoralism 2: 1-21.

Galaty, John, and Elliot Fratkin. 1994. Rangeland tenure and pastoralism in Africa. In African pastoralist systems: An integrated approach, ed. Elliot Fratkin, John Galvin, and Eric Abella Roth, 185-204. London: Lynne Rienner Publishers.

Gautier, Denis, and Hautdidier Baptiste. 2012. Political ecology et émergence de territorialités inattendues: l'exemple de la mise en place de forêts aménagées dans le cadre du transfert d'autorité de gestion au Mali. In Environnement, discours et pouvoir: L'approche Political Ecology, ed. Denis Gautier and Tor A, 241-257. Versailles: Quae: Benjaminsen.

Gautier, Denis, Baptiste Hautdidier, and Laurent Gazull. 2011. Woodcutting and territorial claims in Mali. Geoforum 42: 28-39. doi:10.1016/j. geoforum.2010.08.008.

Gautier, Denis, Bonnérat, Amélie, and Njoya, Aboubakar. 2005. The relationship between herders and trees in space and time in Northern Cameroon. The Geographical Journal 171: 324-339.

Gonin, Alexis, and Bernard Tallet. 2012a. Quel avenir pour l'élevage dans le bassin cotonnier de l'Ouest du Burkina Faso ? Dynamiques agro-pastorales et recompositions territoriales. Autrepart 60: 95-110. doi:10.3917/autr.060.0095.

Gonin, Alexis, and Bernard Tallet. 2012b. Changements spatiaux et pratiques pastorales : les nouvelles voies de la transhumance dans l'Ouest du Burkina Faso. Cahiers Agricultures 21: 448-454.

Gray, Leslie, and Brian Dowd-Uribe. 2013. A political ecology of socio-economic differentiation: Debt, inputs and liberalization reforms in southwestern Burkina Faso. Journal of Peasant Studies 40: 683-702.

Hagmann, Tobias, and Chinwe Ifejika-Speranza. 2010. Introduction: New avenues for pastoral development in sub-Saharan Africa. European Journal of Development Research 22: 593-604.

Hamadou, Seyni, and Jérémy Bouyer. 2007. Production laitière en zone périurbain. Calcul de la rentabilité des fermes. Cirdes/ Cirad. http://www. cirdes.org/IMG/pdf/F21_Rentabilite_fermes.pdf. Accessed 3 October 2014.

Hochet, Peter, and Charles Guissou. 2010. Une Politique D'adaptation Climatique Inachevée Mais Persistante Le Cas de la Zone Pastorale du CEZIET de Samorogouan (Burkina Faso). Sustentabilidade em Debate 1: 30-78.

Hochet, Peter, and Jacob Jean-Pierre. 2012. Comment renégocier l'action publique? Le cas de la zone pastorale de Samorogouan. Gouvernance et citoyenneté.

Horowitz, and M Michael. 1979. The sociology of pastoralism and African livestock projects. 6. Washington DC: Bureau for Program and Policy Coordination, US Agency for International Development.

IUCN. 2006. Global review of the economics of pastoralism. Nairobi: IUCN, WISP.

Keya, and A George. 1991. Alternative policies and models for arid and semi-arid lands in Kenya. In When the grass is gone: Development intervention in African arid lands, ed. T Paul and W Baxter, 151-162. Uppsala: Scandinavian Institute of African Studies.

Lentz, Carola. 2005. First-comers and late-comers: The role of narratives in land claims. In Competing jurisdictions: Settling land claims in Africa, ed. Sandra Evers, Marja Spierenburg, and Harry Wels, 157-180. London: Brill.

Lesorogol, Carolyn K. 2008. Land privatization and pastoralist well-being in Kenya. Development and Change 39: 309-331.

Livingstone, lan. 1991. Livestock management and "overgrazing" among pastoralists. Ambio 20: 80-85.

Marty, André. 1993. La gestion de terroirs et les éleveurs: un outil d'exclusion ou de négociation? Tiers-Monde 34: 327-344.

Mattee, Amon Z, and Martin Ndabikunze Shem. 2006. Ambivalence and contradiction: A review of the policy environment in Tanzania in relation to pastoralism. 140. London: IIED.

Mertz, Ole, Cheikh Mbow, Jonas Østergaard Nielsen, Abdou Maiga, Drissa Diallo, Anette Reenberg, Awa Diouf, Bruno Barbier, Ibrahim Bouzou Moussa, and Malicki Zorom. 2010. Climate factors play a limited role for past adaptation strategies in West Africa. Ecology \& Society 15: 15-25.

Milligan, Simon, and Tony Binns. 2007. Crisis in policy, policy in crisis: understanding environmental discourse and resource-use conflict in northern Nigeria. The Geographical Journal 173: 143-156.

Moritz, Mark. 2012. Pastoral intensification in West Africa: implications for sustainability. Journal of the Royal Anthropological Institute 18: $418-438$. 
Moritz, Mark, Catherine Bebisse Larisa, Albert K Drent, Kari Saïdou, Mouhaman Arabi, and Scholte Paul. 2013. Rangeland governance in an open system: Protecting transhumance corridors in the Far North Province of Cameroon. Pastoralism: Research, Policy and Practice 3:26.

Moutari, Maman Elhadji, and Giraut Frédéric. 2013. Le corridor de transhumance au Sahel: un archétype de territoire multisitué? L'Espace géographique: 306-323.

Mwangi, Esther. 2009. Property rights and governance of Africa's rangelands: A policy overview. Natural Resources Forum 33: 160-170. doi:10.1111/j.14778947.2009.01219.x.

Nelen, Joost, Traoré Nata, and Ouattara Moumouni. 2004. De la colonisation du vide à la concertation sur le plein: Réglementation de l'exploitation d'une zone pastorale à Samorogouan, Burkina Faso. London: International Institute for Environment and Development (IIED).

Oxby, Clare. 1999. Mirages of pastoralist futures: A review of aid donor policy in Sahelian pastoral zones. Review of African Political Economy 26: 227-237.

Painter, Thomas, James Sumberg, and Thomas Price. 1994. Your terroir and my action space': Implications of differentiation, mobility and diversification for the approche terroir in Sahelian West Africa. Africa: Journal of the International African Institute 64: 447-447.

Peluso, Nancy Lee. 2005. Seeing property in land use: Local territorializations in West Kalimantan, Indonesia. Geografisk Tidsskrift-Danish Journal of Geography 105: 1-15.

Petit, Sandrine. 2000. Environnement, conduite des troupeaux et usage de l'arbre chez les agropasteurs peuls de l'Ouest burkinabé. Approche comparative et systématique de trois situations. Barani, Kourouma, Ouangolodougou: Thèse de doctorat, Orléans: Université d'Orléans, Cirad, IRD, Cirdes.

Plan d'actions et programme d'investissements du sous-secteur de l'élevage 2010-2015. 2010. Ouagadougou: Ministère des ressources animales.

Politique nationale de développement durable de l'élevage au Burkina Faso. 2010. Ouagadougou: Ministère des ressources animales.

Rohde, F Richard, M Nkobi, Moleele, Mphale Mphale, Allsopp Nicky, Chanda Raban, Hoffman Timm, G Lapologa Magole, and Young Einir. 2006. Dynamics of grazing policy and practice: Environmental and social impacts in three communal areas of southern Africa. Environmental Science \& Policy 9: 302-316. doi:10.1016/j.envsci.2005.11.009.

Sack, Robert D. 1983. Human territoriality: A theory. Annals of the Association of American Geographers 73: 55-74.

Sandford, Stephen. 1983. Management of pastoral development in the Third World. Chichester: Wiley.

Sautter, Gilles, and Pélissier Paul. 1964. Pour un atlas des terroirs africains: Structure-type d'une étude de terroir. L'homme: 56-72.

Schwartz, Alfred. 1997. Des temps anciens à la dévaluation du franc CFA, les tribulations de la culture du coton au Burkina Faso. Annales de géographie 106: 288-312.

Scoones, lan. 1994. Living with uncertainty: New directions in pastoral development in Africa, vol. 6. London: Intermediate Technology Publications.

Scoones, lan. 1999. New ecology and the social sciences: What prospects for a fruitful engagement? Annual Review of Anthropology 28: 479-507.

Stratégie d'aménagement, de sécurisation et de valorisation des espaces et aménagements pastoraux. 2009. Ouagadougou: Ministère des ressources animales.

Tallet, Bernard. 1997. La brousse est finie. In Développement durable au Sahel, ed. Philippe Tersiguel and Charles Becker, 167-179. Paris: Karthala.

Tersiguel, Philippe. 1995. Le pari du tracteur. La modernisation de I'agriculture cotonnière au Burkina Faso. Paris: Orstom éditions.

Thébaud, Brigitte, and Simon Batterbury. 2001. Sahel pastoralists: Opportunism, struggle, conflict and negotiation. A case study from eastern Niger. Global Environmental Change 11: 69-78.

Tonah, Steve. 2003. Integration or exclusion of Fulbe pastoralists in West Africa: A comparative analysis of interethnic relations, state and local policies in Ghana and Côte d'Ivoire. Journal of Modern African Studies 41: 91-114.

Turner, Matthew D. 1998. The interaction of grazing history with rainfall and its influence on annual rangeland dynamics in the Sahel. In Nature's geography: New lessons for conservation in developing countries, ed. Karl S Zimmerer and Kenneth R Young, 237-261. Madison: University of Wisconsin Press.
Turner, Matthew D. 1999. Conflict, environmental change, and social institutions in dryland Africa: Limitations of the community resource management approach. Society \& Natural Resources 12: 643-657.

Turner, Matthew D. 2009. Capital on the move: The changing relation between livestock and labor in Mali, West Africa. Geoforum 40: 746-755.

Turner, Matthew D. 2011. The new pastoral development paradigm: Engaging the realities of property institutions and livestock mobility in dryland Africa. Society \& Natural Resources 24: 469-484. doi:10.1080/08941920903236291.

Turner, Matthew D, and Timothy O Williams. 2002. Livestock market dynamics and local vulnerabilities in the Sahel. World Development 30: 683-705.

Turner, Matthew D, John G McPeak, and Augustine Ayantunde. 2014. The role of livestock mobility in the livelihood strategies of rural peoples in semi-arid West Africa. Human Ecology 42: 231-247. doi:10.1007/s10745-013-9636-2.

Upton, Martin. 1986. Production policies for pastoralists: The Borana case. Agricultural Systems 20: 17-35.

Vall, Éric, and Mohamadoun Amadou Diallo. 2009. Savoirs techniques locaux et pratiques: la conduite des troupeaux aux pâturages (Ouest du Burkina Faso). Natures Sciences Sociétés 17: 122-135.

Vall, Éric, Patrick Dugué, and Mélanie Blanchard. 2006. Le tissage des relations agriculture-élevage au fil du coton. Cahiers Agricultures 15: 72-79.

Wayne, A. 2006. Review of the literature on pastoral economics and marketing. Nairobi: WISP, UICN

Western, David. 1982. The environment and ecology of pastoralists in arid savannas. Development and Change 13: 183-211. doi:10.1111/j.14677660.1982.tb00117.x.

Zimmerer, Karl S. 1994. Human geography and the "new ecology": The prospect and promise of integration. Annals of the Association of American Geographers 84: 108-125.

Zimmerer, Karl S. 2000. The reworking of conservation geographies: Nonequilibrium landscapes and nature-society hybrids. Annals of the Association of American Geographers 90: 356-369.

\section{Submit your manuscript to a SpringerOpen ${ }^{\circ}$ journal and benefit from:}

- Convenient online submission

Rigorous peer review

- Immediate publication on acceptance

- Open access: articles freely available online

- High visibility within the field

- Retaining the copyright to your article

Submit your next manuscript at $>$ springeropen.com 